The Rise and Decline of Nations 



\section{THE RISE AND DECLINE OF NATIONS}

Economic Growth, Stagflation, and Social Rigidities

\section{Mancur Olson}

Yale University Press

New Haven and London 
Table 7.1 is reprinted from The Jacksonian Democracy by Peter Temin (New York: W. W. Norton, 1969) by permission of the publisher.

Copyright (C) 1982 by Yale University.

All rights reserved.

This book may not be reproduced, in whole or in part, in any form (beyond that copying permitted by Sections 107 and 108 of the U.S. Copyright Law and except by reviewers for the public press), without written permission from the publishers.

Designed by James J. Johnson and set in Times Roman type by The Composing Room of Michigan, Inc. Printed in the United States of America by Courier Companies, Inc.

\section{Library of Congress Cataloging in Publication Data}

Olson, Mancur.

The rise and decline of nations.

Includes bibliographical references and index.

1. Economic development. 2. Unemployment-Effect of inflation on. 3. Caste-India. 4. Economics.

I. Title.

\begin{tabular}{|c|c|c|}
\hline HD82.0565 1982 & $338.9^{\prime} 001$ & $82-40163$ \\
\hline ISBN 0-300-02307-3 & & AACR2 \\
\hline $0-300-03079-7$ & & \\
\hline
\end{tabular}


For Ellika, Mancur Severin, and Sander 
